\title{
Strategic wet season supplementation of traditionally managed N'Dama cows using sesame cake produced in Gambian villages
}

\author{
D. A. Littlet, J. C. Tanner, E. Sonko and E. Saho \\ International Trypanotolerance Centre, PMB 14, Banjul, The Gambia
}

\section{Introduction}

Trypanotolerant N'Dama cattle are indigenous to The Gambia and southern Senegal, where the extraction of milk for human consumption is of major importance in the traditional husbandry systems, and in which the presence of the calf to initiate milk let-down is essential (Agyemang, Jeannin, Grieve, Bah and Dwinger, 1988). The food supplies of these cattle are almost exclusively restricted to natural pastures and browse, and the seasonal availability of various crop residues. Available forage varies markedly in both quality and quantity throughout the year, and the 8-month dry season invariably is associated with substantial nutritional stress. Previous work has shown that dry season supplementation of lactating village cows with small quantities of locally available proteinaceous agro-industrial by-products has produced marked increases in productivity, sustainable in economic terms (Little, Riley, Agyemang, Jeannin, Grieve, Badji and Dwinger, 1991). This paper demonstrates similar responses to such supplementation during the wet season.

\section{Material and methods}

Traditionally managed N'Dama cattle in the Gambian village of Keneba, monitored in terms of health and productivity characteristics for 5 years (Jeannin, Dwinger, Agyemang and Grieve, 1987), were used in this experiment. Three groups of 15 cows averaging 9 months into lactation at the onset of the wet season were randomly allocated to be supplemented for 3 months (August to October) with locally produced sesame cake at rates of 0,425 or $850 \mathrm{~g}$ per head per day, given as 1 or $2 \mathrm{~kg}$ on three mornings per week. Two cows initially reluctant to accept the supplement were moved to the control group. Cows and calves were weighed monthly, and milk offtake for human consumption measured twice monthly, from August 1990 to February 1991. Rates

+ Also a member of staff of the International Livestock Centre for Africa (ILCA). Present address: ILCA, PMB 2248, Kaduna, Nigeria. of live-weight change were calculated for individual animals by linear regression of live weight on time: these data and those of milk offtake were examined for treatment effects by analysis of variance.

\section{Results and discussion}

Total milk offtake per cow from control, 425 and $850 \mathrm{~g} /$ day groups during the period of supplementation averaged 96, 152 and 1731 respectively, both supplemented groups significantly exceeding the controls $(P<0.05$, Table 1$)$, but not so differing from each other. This advantage was maintained after supplementation ceased, so that by 4 months into the dry season (February) the total offtake from the supplemented groups still exceeded that from the controls by a mean of proportionately 0.76 (131 v. 222 and $2401, P<0.05$ ). Rates of liveweight gain of both supplemented cows and their calves tended to exceed those of control animals, but only while supplementation continued, and were statistically significant only for the cows receiving $850 \mathrm{~g} /$ day (Table 1). Preliminary results from plasma progesterone determinations indicate conception. rates of $35 \%$ and $60 \%$ respectively among control and supplemented animals. These await confirmation, but such improvement would be consistent with findings from comparable dry season regimes (Little et al., 1991).

Table 1 Milk offtake and live-weight gain ( $L W G$ ) during supplementation of lactating $N^{\prime}$ Dama cows under village husbandry, given sesame cake during the wet season (August to October) in The Gambia

\begin{tabular}{cccc}
\hline \hline $\begin{array}{c}\text { Sesame } \\
\text { cake } \\
\begin{array}{c}\text { (g per head } \\
\text { per day) }\end{array}\end{array}$ & $\begin{array}{c}\text { Total } \\
\text { milk } \\
\text { offtake (1) }\end{array}$ & $\begin{array}{c}\text { Cow } \\
\text { LWG } \\
\text { (g/day) }\end{array}$ & $\begin{array}{c}\text { Calf } \\
\text { LWG } \\
\text { (g/day) }\end{array}$ \\
\hline 0 & $96^{\text {a }}$ & $57^{\mathrm{a}}$ & 74 \\
425 & $152^{\mathrm{b}}$ & $116^{\mathrm{a}}$ & 107 \\
850 & $173^{\mathrm{b}}$ & $244^{\mathrm{b}}$ & 93 \\
s.e. & $17 \cdot 6$ & $55 \cdot 2$ & $20 \cdot 2$ \\
\hline \hline
\end{tabular}

$a, b$ Within columns, means with different superscripts differ significantly at $P<0 \cdot 05$. 
Three calves in the control group (17\%) died during the period of observation, comparable with a $24 \%$ calf mortality previously recorded from this village (Jeannin et al., 1987). However, no calves of supplemented cows died, suggesting that wet season supplementation was of benefit in this respect, as has been observed also from similar regimes in the dry season (D. A. Little, unpublished data).

Sesame cake was purchased from a local mill at D0 $50 / \mathrm{kg}$ (Gambian Dalasis, D15 = $€ 1$ approx.), rendering the total cost of supplementing each cow approximately D20 or D40 for the low and high rates respectively. The market value of milk in the village is D2.25/1, so that the value of the extra milk produced during the supplementation period exceeded the cost of the supplement by at least twofold, and by February by more than five-fold. Such intervention is thus economically viable on the basis of milk production alone; other productivity benefits that may accrue, such as reduced calf mortality and improved reproductive rate, will render it even more so.

\section{Acknowledgements}

The work formed part of a project executed jointly by ILCA and ILRAD funded by the European Development Fund. JCT was supported by the Overseas Development Administration.

\section{References}

Agyemang, K., Jeannin, P., Grieve, A. S., Bah, M. L. and Dwinger, R. H. 1988. Milk extraction for human consumption from N'Dama cattle under village management conditions in The Gambia. In Livestock production in tsetse affected areas of Africa. Proceedings of ILCAI ILRAD meeting, Nairobi, 1987, pp. 231-245.

Jeannin, P., Dwinger, R. H., Agyemang, K. and Grieve, A. S. 1987. Epidemiological investigations on N'Dama cattle in The Gambia. Proceedings of the 19th meeting of International Scientific Council for Trypanosomiasis Research and Control, Lome, Togo (OAL/STRC, Nairobi, Kenya), pp. 222-233.

Little, D. A., Riley, J. A., Agyemang, K., Jeannin, P., Grieve, A. S., Badji, B. and Dwinger, R. H. 1991. Effect of groundnut cake supplementation during the dry season on productivity characteristics of N'Dama cows under village husbandry conditions in The Gambia. Tropical Agriculture, Trinidad In press. 